\title{
Serum-cholesterol levels and atherosclerosis: effects of composition of diet and tri-iodothyronine on the rat
}

\author{
By W. F. J. CUTHBERTSON, P. V. ELCOATE, D. M. IRELAND, \\ D. C. B. MILLS AND PATRICIA SHEARLEY \\ Glaxo Laboratories Ltd, Greenford, Middlesex \\ (Received 8 November 1958-Revised 2 Fanuary 1959)
}

Several dietary components have been shown to affect the concentration of serum cholesterol, e.g. the type and amount of carbohydrate and fat (Portman, Mann \& Wysocki, 1955; Hegsted, Andrus, Gotsis \& Portman, 1957), the amount of protein and magnesium (Moyer, Kritchevsky, Logan \& Cox, 1956; Vitale, White, Nakamura, Hegsted, Zamcheck \& Hellerstein, 1957; Hellerstein, Vitale, White, Hegsted, Zamcheck \& Nakamura, I957), the amount of cholic acid and cholesterol (Swell, Flick, Field \& Treadwell, I953; Hegsted et al. I957), and the amount of choline chloride (Weiss, Marx \& Marx, 1952; Moyer et al. 1956). In the adult rat the concentration of serum cholesterol appears to determine the degree of atherosclerosis produced (Hegsted et al. 1957), although other factors may also be concerned in the young rat (Vitale et al. 1957).

The work described here has been carried out to extend these observations, and some of the above variables have been studied again in weanling albino rats of the WAG strain.

$3,5,3^{\prime}$-tri-iodo-L-thyronine has been shown to reduce the concentration of serum cholesterol in man (Oliver \& Boyd, I956). This compound was tested to determine whether it would act similarly in the rat and to compare its effect with that of $\mathrm{L}$-thyroxine, which has been shown to reduce serum cholesterol levels and partly to prevent the development of atherosclerosis in rats on a diet producing hypercholesterolaemia (Vitale et al. 1957).

\section{METHODS}

Rats. Male and female weanling rats of the WAG strain were used at ages of from 2 I to 25 days, weighing $35^{-50} \mathrm{~g}$. They were distributed at random, not more than five to a cage, and were kept, with food and tap water available at all times, in a room at $24 \pm 2^{\circ}$.

Diets. Several diets were used (Cuthbertson, Elcoate, Ireland, Mills \& Shearley, 1958). All are variants of two basic diets, a stock diet (A) and a high-fat diet (B), whose compositions are given in Table $\mathbf{I}$.

$3,5,3^{\prime}$-tri-iodo-L-thyronine $\left(T_{3}\right)$. The compound was dissolved in $0 \cdot 1 \mathrm{~N}-\mathrm{NaOH}$, diluted with ethanol and mixed in $\operatorname{diet} \mathrm{B}$ at the concentrations indicated. 
either by cutting the tip of the tail or, after anaesthesia and opening of the thorax, from the heart. When tail blood was used the fact is stated in the appropriate place. The concentration of cholesterol was determined on fresh samples of serum, the reaction mixture being shielded from direct sunlight. A.R. acetic acid was refluxed for $3 \mathrm{~h}$ over chromium trioxide $(8 \mathrm{~g} / 1$. acetic acid) and distilled before use. Usually the amount of cholesterol in the serum of individual rats was determined, but sometimes equal amounts of serum from several rats were used to determine the cholesterol content of the pooled serum.

\section{Table I. Percentage compositions of the diets}

Diet A

Wholemeal wheat flour

Roller-dried full-cream milk

(approximate fat content $27 \%$ )

Dried brewer's yeast

Vitamin mixture $\dagger$

\begin{tabular}{llr}
\multicolumn{2}{c}{ Diet B } \\
70 & $25 \cdot 0$ \\
25 & $\begin{array}{l}\text { Crude casein } \\
\text { Hydrogenated arachis oil } \\
\left.\text { (m.p. } 32-34^{\circ}\right)^{*}\end{array}$ & $22 \cdot 0$ \\
Maize starch (Brown and & $45 \cdot 5$ \\
Polson Ltd, London) & \\
Cholesterol & $2 \cdot 0$ \\
Cholic acidf $\ddagger$ & $0 \cdot 5$ \\
& Choline chloride & $1 \cdot 0$ \\
& Salt mixtureई & $4 \cdot 0$
\end{tabular}

Diet B was modified by substituting arachis oil, $\|$ maize oil $\|$ or equal parts (by weight) of arachis oil and maize oil for the hydrogenated arachis oil where shown in parentheses in the text and tables. Concentrations of cholesterol, cholic acid and choline chloride were as given above except when otherwise stated. Cholesterol added to diet A replaced wheat flour; cholesterol, cholic acid and choline chloride, when omitted from diet $B$, were replaced by maize starch.

* British Oil and Cake Mills Ltd, Erith.

+ Vitamin mixture/kg diet: vitamin A palmitate, $2 \cdot 2 \mathrm{mg}$; ergocalciferol, $50 \mu \mathrm{g}$; DL- $\alpha$-tocopheryl acetate, $280 \mathrm{mg}$; vitamin $\mathrm{K}$ (menaphthone, 2-methyl-1:4-naphthoquinone), $2 \mathrm{mg}$; inositol, $220 \mathrm{mg}$; thiamine hydrochloride, $30 \mathrm{mg}$; riboflavin, $30 \mathrm{mg}$; nicotinic acid, $100 \mathrm{mg}$; cyanocobalamin, $50 \mu \mathrm{g}$; biotin, $200 \mu \mathrm{g}$; pteroylglutamic acid, I $\mathrm{mg}$; pyridoxine, $8 \mathrm{mg}$; Ca-D-pantothenate, I00 $\mathrm{mg}$. Fat-soluble vitamins were added in $2 \mathrm{~g}$ of the appropriate oil.

I Union International Company Ltd, London.

$\S$ Salt mixture (modified from that of Hubbell, Mendel \& Wakeman, 1937): $\mathrm{CaCO}_{3}, \mathrm{I} 629 \mathrm{~g} ; \mathrm{MgCO}_{3}$, $75 \mathrm{~g}, \mathrm{MgSO}_{4} \cdot 7 \mathrm{H}_{2} \mathrm{O}, 99 \mathrm{~g} ; \mathrm{NaCl}, 207 \mathrm{~g} ; \mathrm{KCl}, 336 \mathrm{~g} ; \mathrm{KH}_{2} \mathrm{PO}_{4}, 636 \mathrm{~g} ; \mathrm{FePO}_{4} \cdot 4 \mathrm{H}_{2} \mathrm{O}, 6 \mathrm{r} \cdot 5 \mathrm{~g} ; \mathrm{KI}$, $240 \mathrm{mg} ; \mathrm{MnSO}_{4} \cdot{ }_{4} \mathrm{H}_{2} \mathrm{O}, \mathrm{I}_{5} \cdot 5 \mathrm{~g} ; \mathrm{NaF}, 3 \mathrm{~g} ; \mathrm{Al}_{2}\left(\mathrm{SO}_{4}\right)_{3} . \mathrm{K}_{2} \mathrm{SO}_{4} \cdot 24 \mathrm{H}_{2} \mathrm{O}, 930 \mathrm{mg} ; \mathrm{CuSO}_{4} \cdot{ }_{5} \mathrm{H}_{2} \mathrm{O}, 4_{4} \cdot 5^{6} \mathrm{~g}$; $\mathrm{Na}_{2} \mathrm{MoO}_{4} \cdot 2 \mathrm{H}_{2} \mathrm{O}, 25 \mathrm{mg}$.

II Medina Refinery Ltd, Deptford.

Liver cholesterol. Livers, removed immediately after the animals were killed, were rinsed in saline, blotted and homogenized in a variable-speed micro-homogenizer (M.S.E. Ltd, London). A portion of the homogenate was weighed, dried at $100^{\circ}$ for I $6 \mathrm{~h}$, reweighed and extracted with a $\mathrm{I}: \mathrm{I}$ mixture of redistilled methanol and A.R. chloroform for $3 \mathrm{~h}$. The volume of the extract was measured, and a portion containing $0.1-0.4 \mathrm{mg}$ cholesterol was evaporated to dryness over a water-bath. The residue was then dissolved in purified acetic acid and the cholesterol content determined by the method of Zlatkis et al. (I953). Livers from animals receiving the same treatment were pooled and treated as one sample. The concentration of cholesterol was calculated for the weight of the undried homogenate.

Sudan stain. The heart, pulmonary arteries and aorta, with the roots of the major branches, were dissected out, opened along the ventral surfaces, spread on filter-paper, fixed in formalin-saline and stained with sudan IV to demonstrate lipid deposits 
(Fillios, Andrus, Mann \& Stare, I956). The internal surfaces were examined for stained material with a low-power microscope, and eight areas were scored from $\circ$ to 4 according to the extent and intensity of staining. These were: the abdominal and the thoracic aorta; the aortic arch; the aortic, mitral, tricuspid and pulmonary valves; and the pulmonary arteries. The total score from these eight areas is called the sudan score. All the samples were scored by one person after being coded by another to reduce subjective bias.

Heart lesions. White areas were visible in the unfixed cardiac muscle of some rats fed on certain of the test diets. These lesions were seen at the base of the aortic valves and on the papillary muscles when the left ventricle was opened by a ventral cut from the apex into the aorta. Similar but smaller areas were seen at or near the apex of the unopened heart.

Statistics. Comparison between the results of two treatments was made by the $t$ test. Although the differences between the variances of compared means were sometimes significant, the $t$ test was found to be satisfactory because the degrees of freedom were always the same or nearly so.

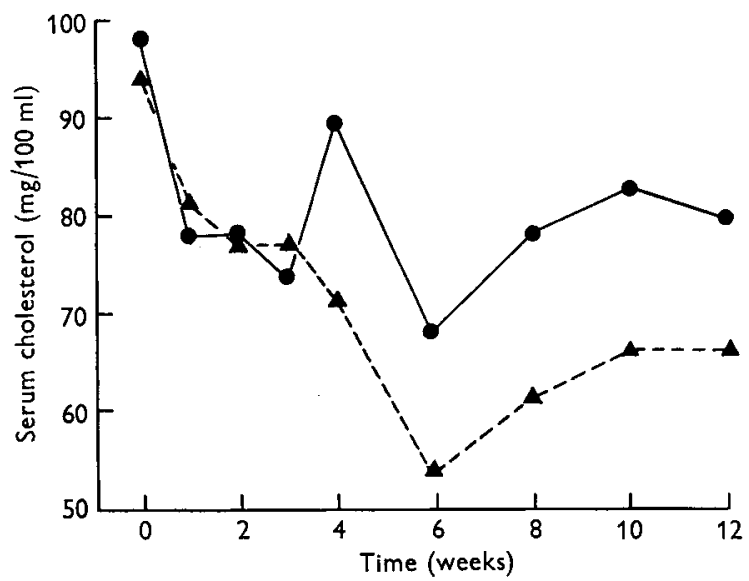

Fig. I. Concentration of cholesterol in the serum of male, $\mathbf{\Delta}$, and female, $\bullet$, rats, receiving diet $\mathbf{A}$ from weaning. Each point represents the mean value for nine or ten rats. Tail blood was withdrawn from the rats receiving the diet for 12 weeks, heart blood from the others.

RESULTS

Diet $A$

Serum cholesterol. Results are shown in Fig. I. At weaning the serum was milky in appearance and contained $94-98 \mathrm{mg}$ cholesterol/roo $\mathrm{ml}$ serum. The milkiness disappeared and the cholesterol concentration fell within I week to $78-8 \mathrm{I} \mathrm{mg} / \mathrm{roo} \mathrm{ml}$ and remained at about this level for the next 2 weeks. A significant difference between the concentrations of cholesterol in the serum of the male and the female rats developed after 4 weeks $(P<0.001)$, and this difference persisted during the next 8 weeks.

Sudan score. Apart from an occasional small, lightly staining area at the base of an aortic valve cusp, no material staining with sudan IV was seen during the 12-week observation period. 


\section{Preliminary experiments with diets producing hypercholesterolaemia}

When diet B (arachis oil) was given to weanling rats, the concentrations of cholesterol in the serum of both sexes increased about fivefold, reaching a maximum after 7-1 4 days. As with diet $A$, there was no significant difference between the concentrations of cholesterol in the serum of the two sexes during the first 3-4 weeks. After this time, however, the serum of female rats showed significantly greater concentrations of cholesterol than that of the males.

Serum-cholesterol determinations were therefore made on weanling rats given various diets for $\mathrm{I}_{4}$ days, i.e. at the time when, according to the preliminary observations, the cholesterol concentration would be at its peak and before a sex difference had developed.

\section{Effect of cholic acid}

When the amount of cholic acid in diet B (arachis oil) was increased from $\circ$ to $0.25 \%(\mathrm{w} / \mathrm{w})$ or from 0.25 to $0.5 \%(\mathrm{w} / \mathrm{w})$ the concentrations of serum cholesterol and of liver cholesterol increased (Table 2$)$. However, $\mathrm{x} \%(\mathrm{w} / \mathrm{w})$ cholic acid reduced the rate of growth, and the cholesterol concentrations in both liver and serum were lower than with $0.5(\mathrm{w} / \mathrm{w})$ cholic acid.

Table 2. Effect of dietary cholic acid on concentration of cholesterol in serum and liver

(Mean values with their standard errors for groups of ten male and ten female rats receiving type $B$ (arachis oil) diets for 14 days from weaning)

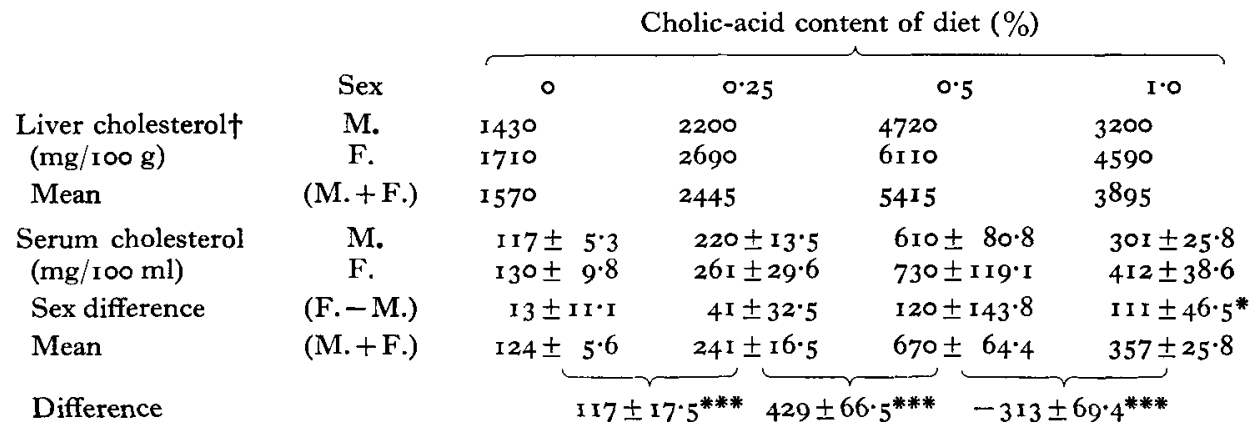

* $P<0.05$ *** $P<0.001$.

$\uparrow$ Each determination was done on a portion of the pooled livers from ten rats.

\section{Effect of choline chloride}

The omission of choline chloride from diet $\mathrm{B}$ (arachis oil) led to a fall in the concentration of serum cholesterol (Table 3 ). In this experiment reduction of the cholinechloride content to $0.25 \%(\mathrm{w} / \mathrm{w})$ had no effect on the concentration of cholesterol in the serum of male rats, but increased that of female rats. In another experiment $1.0 \%$ $(\mathrm{w} / \mathrm{w})$ choline chloride produced higher levels of serum cholesterol than $0.25 \%(\mathrm{w} / \mathrm{w})$ in both male and female rats, but was associated with a low rate of growth. A difference in the mean initial weights of the weanling rats used in the two experiments may have accounted for the different results obtained. 
The concentrations of liver cholesterol in the female rats were higher than those in the males, but the choline content of the diet had no effect on the liver cholesterol of either male or female rats in any experiments.

\section{Table 3. Effect of dietary choline chloride on concentration of cholesterol in serum and liver}

(Mean values with their standard errors from three experiments done at different times. In each, ten male and ten female rats received type B (arachis oil) diets for 14 days from weaning. Two female rats died during the experiments)

\begin{tabular}{|c|c|c|c|c|}
\hline \multirow{2}{*}{\multicolumn{2}{|c|}{ Sex }} & \\
\hline & & $\circ$ & 0.25 & $1 \cdot 0$ \\
\hline $\begin{array}{l}\text { Liver cholesterol } \dagger \\
(\mathrm{mg} / \mathrm{l} 00 \mathrm{~g})\end{array}$ & $\begin{array}{l}\text { M. } \\
\text { F. }\end{array}$ & $\begin{array}{l}3620 \\
5080\end{array}$ & $\begin{array}{l}4235 \\
5230\end{array}$ & $\begin{array}{l}4310 \\
5000\end{array}$ \\
\hline Mean & $(\mathrm{M} .+\mathrm{F})$. & $435^{\circ}$ & 4732 & 4655 \\
\hline $\begin{array}{l}\text { Serum cholesterol } \\
(\mathrm{mg} / \mathrm{l} 00 \mathrm{ml})\end{array}$ & $\begin{array}{l}\text { M. } \\
\text { F. }\end{array}$ & $\begin{array}{l}228 \pm 26 \cdot 4 \\
3 \text { I } 3 \pm 32 \cdot 6\end{array}$ & $\begin{array}{l}462 \pm 39 \cdot 5 \\
702 \pm 61 \cdot 0\end{array}$ & $\begin{array}{l}455 \pm 39 \cdot 5 \\
521 \pm 38 \cdot 1\end{array}$ \\
\hline Sex difference & (F. - M.) & $85 \pm 42 \cdot 0^{*}$ & $240 \pm 72 \cdot 7^{* *}$ & $66 \pm 54^{\circ} 9$ \\
\hline Mean & (M. + F.) & $270 \pm 21 \cdot 4$ & $580 \pm 39 \cdot 1$ & $488 \pm 27 \cdot 5$ \\
\hline Difference & $\begin{array}{c}\text { M. } \\
\text { F. }\end{array}$ & $\begin{array}{l}23 \\
380\end{array}$ & $\begin{array}{r}-7 \\
-\mathrm{I} 8\end{array}$ & $\begin{array}{l}9 \\
9^{* *}\end{array}$ \\
\hline
\end{tabular}

* $P<0.05$. *** $P<0.01$.

$\dagger$ Each value is the mean of three determinations. Each determination was done on a portion of the pooled livers from nine or ten rats.

\section{Effect of different fats}

Fig. 2 shows the result of substituting various fats in diet B. Four groups of rats, each group containing males and females, were fed on diet $B$ modified to contain either maize oil, equal parts of maize oil and arachis oil, arachis oil or hydrogenated arachis oil. In this order, the concentration of serum cholesterol in each group was higher than in the preceding group. Further experiments have confirmed the differences between the effects of maize oil, arachis oil and hydrogenated arachis oil on the serum cholesterol of rats on diets containing $\mathrm{I} \cdot 0 \%(\mathrm{w} / \mathrm{w})$ choline chloride.

\section{Effect of cholesterol}

When $1 \%(w / w)$ cholesterol was added to $\operatorname{diet} A$, the concentrations of cholesterol in the serum and in the livers of both sexes increased. Both cholesterol concentrations were lowered when cholesterol was omitted from diet B (arachis oil) (Table 4).

\section{Diet $B$}

With this diet high serum-cholesterol levels were rapidly achieved. Fig. 3 shows the development of a difference between the concentrations of cholesterol in the serum of weanling male and female rats on diet B. The concentrations of cholesterol in the serum of male rats first increased and then steadily decreased after about 2 weeks, the fall coinciding with puberty, as shown by increased gonad weight. This decrease in the concentration of serum cholesterol did not occur in female rats at puberty; 


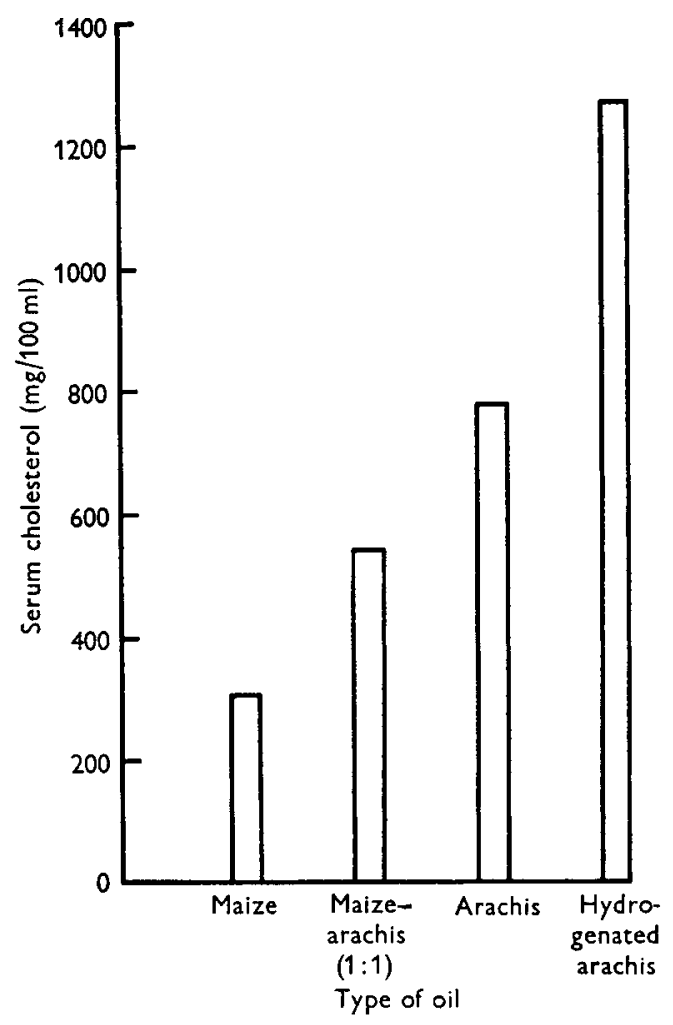

Fig. 2. Concentration of cholesterol in the serum of rats receiving maize oil, maize oil and arachis oil $(I: I)$, arachis oil or hydrogenated arachis oil as part of diet $B$. Each fat was given as $22 \%(w / w)$ of the diet to four male rats and four female rats for I4 days from weaning. Each column represents the mean of two determinations. One determination was made on the pooled serum of four male rats and the other on the pooled serum of four female rats (see p. 227).

\section{Table 4. Effect of dietary cholesterol on concentration of cholesterol in serum and liver}

(Mean values with their standard errors for groups of ten male and ten female rats receiving the diets for 14 days from weaning)

Diet

\begin{tabular}{|c|c|c|c|c|c|}
\hline & & \multicolumn{4}{|c|}{ Diet } \\
\hline & Sex & $\begin{array}{c}\text { A } \\
\text { (no } \\
\text { cholesterol } \\
\text { added) }\end{array}$ & $\begin{array}{c}\text { A } \\
\text { (I \% } \\
\text { cholesterol } \\
\text { added) }\end{array}$ & $\begin{array}{c}\text { B (arachis oil) } \\
\text { (no } \\
\text { cholesterol } \\
\text { added) }\end{array}$ & $\begin{array}{c}\text { B (arachis oil) } \\
(2 \% \\
\text { cholesterol } \\
\text { added })\end{array}$ \\
\hline $\begin{array}{l}\text { Liver cholesterol } \uparrow \\
(\mathrm{mg} / \mathrm{r} 00 \mathrm{~g})\end{array}$ & $\begin{array}{l}\text { M. } \\
\text { F. }\end{array}$ & $\begin{array}{l}15 I \\
252\end{array}$ & $\begin{array}{l}775 \\
580\end{array}$ & $\begin{array}{l}1215 \\
1440\end{array}$ & $\begin{array}{l}4060 \\
4380\end{array}$ \\
\hline Mean & $(\mathrm{M} .+\mathrm{F})$. & 201 & 677 & 1327 & 4220 \\
\hline $\begin{array}{l}\text { Serum cholesterol } \\
(\mathrm{mg} / 100 \mathrm{ml})\end{array}$ & $\begin{array}{l}\text { M. } \\
\text { F. }\end{array}$ & $\begin{array}{l}76 \cdot 8 \pm 3 \cdot 6 \\
78 \cdot 0 \pm 3 \cdot 5\end{array}$ & $\begin{array}{l}106 \cdot 2 \pm 6 \cdot 7 \\
109 \cdot 6 \pm 6 \cdot 3\end{array}$ & $\begin{array}{l}193 \pm 24 \cdot 0 \\
218 \pm 33 \cdot 2\end{array}$ & $\begin{array}{l}485 \pm 86 \cdot 1 \\
576 \pm 73 \cdot 9\end{array}$ \\
\hline Mean & $(\mathrm{M} .+\mathrm{F})$. & $77 \cdot 4 \pm 2 \cdot 2$ & $107 \cdot 9+4^{\circ} 5$ & $205 \pm 20 \cdot 2$ & $53 \circ \pm 56 \cdot 2$ \\
\hline Difference & & $30 \cdot$ & o*** & 325 & $59 \cdot 7^{* * * *}$ \\
\hline
\end{tabular}

*** $P<0.001$.

$\dagger$ Each determination was done on a portion of the pooled livers from ten rats. 
hence only female rats were used in the longer-term studies (Tables 5 and 6 , and Fig. 7).

Fig. 4 shows the changes in the concentration of serum cholesterol in adult animals (initial age $\mathrm{I} 5$ weeks and weight about $\mathrm{I} 50 \mathrm{~g}$ ). The concentrations of serum cholesterol were lower in the males than in the females throughout the experiment. During the 8-week period the concentration of serum cholesterol did not attain, in either sex, values as high as those observed in the young rats.

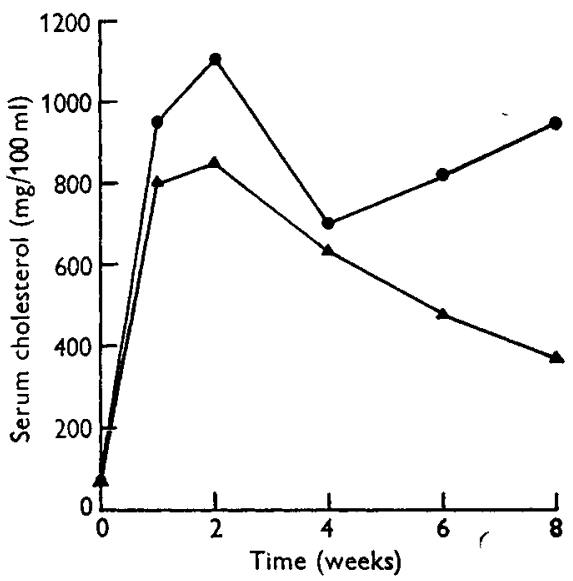

Fig. 3

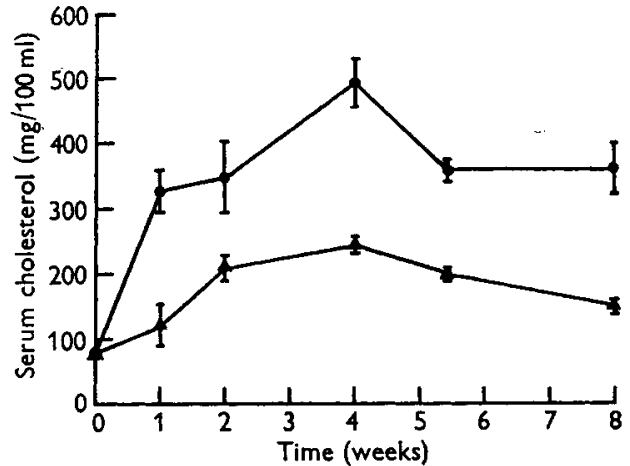

Fig. 4

Fig. 3. Concentration of cholesterol in the serum of male, $\Delta$, and female, $\bullet$, rats receiving diet $B$ from weaning. Each point represents the mean value for five to ten rats.

Fig. 4. Concentration of cholesterol in the serum of adult male, $\Delta$, and adult female, $\bullet$, rats, receiving diet $B$. The rats were 15 weeks old at the beginning of the experiment. Each point represents the mean value for five rats. The lengths of the vertical lines through the points represent twice the standard errors of the means. Tail blood was withdrawn from those rats receiving the diet for 8 weeks, and heart blood from the others.

Sudan score. After 7 days on diet B weanling female rats showed on the aortic valve small areas containing material that stained with sudan IV. After 4 weeks the aortic valve, aortic arch, mitral valve and pulmonary arteries took up the stain. The pulmonary and the tricuspid valves stained less, and in the thoracic and the abdominal sections of the aorta staining was limited to a few small areas. After a further 8 weeks the extent and intensity of staining had increased in all the areas examined (Table 5). Some of the adult animals used for the tests summarized in Fig. 4 were examined for sudanophilic lesions after 8 weeks on treatment; a few lesions were observed in the female rats (sudan score $3^{-5}$ ), but male animals (sudan score 0.25) did not differ significantly in this respect from rats of the same age maintained on stock diet.

Heart lesions. After 8-12 weeks with diet $\mathrm{B}$, involved areas were seen in the myocardium of nearly every heart examined. These lesions have been examined histologically and appear to consist of intracellular deposits of anisotropic lipid material, probably cholesterol, and a little fibrous tissue, demonstrated with van Gieson's stain. Neither occlusion of the coronary vessels nor the usual signs of necrosis were seen, and there is no evidence for believing that these lesions were caused by infarction. 
岁焉樆

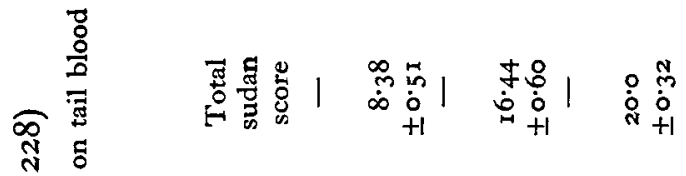

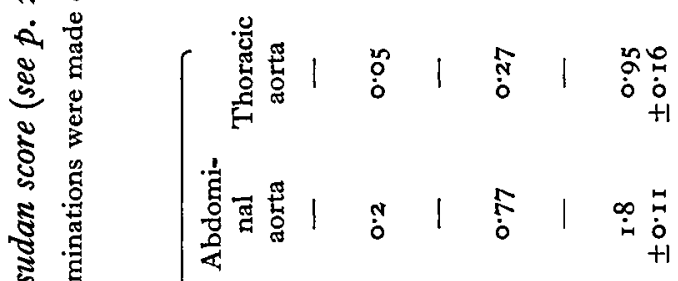

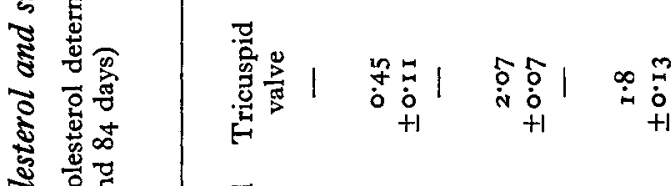

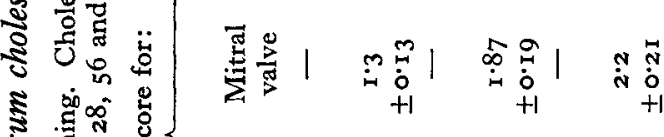

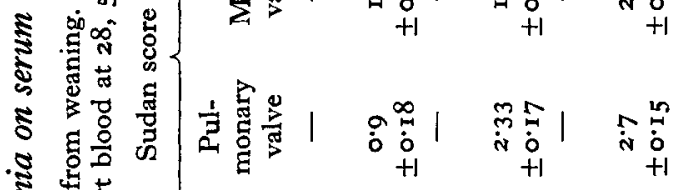

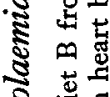

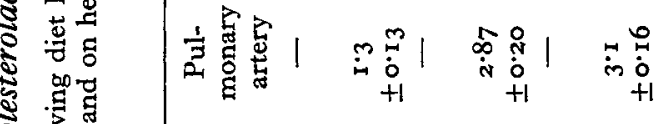

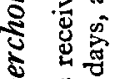

究密员

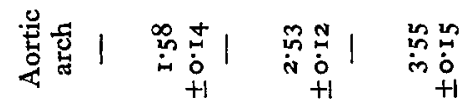

कo 웜

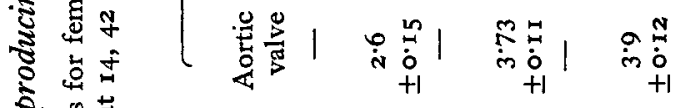

空

ษ

के

巡

通

in

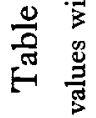

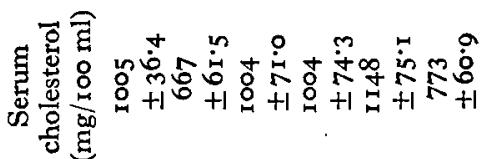

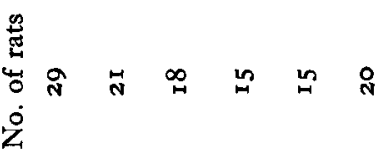

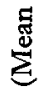

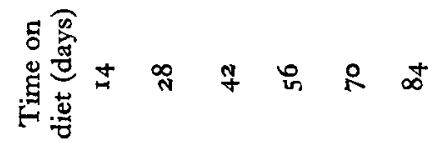




\section{Relation between sudan score and serum cholesterol}

Our results (Table 5) agree substantially with the findings of Fillios et al. (1956) that sudan-staining material accumulates predominantly in the pulmonary arteries, the aortic and mitral valves and the aortic arch. The lesions appeared first at the base of the aortic and mitral valves and along the line of closure of the valve flaps, as has been recorded by Deming, Mosbach, Bevans, Daly, Abell, Martin, Brun, Halpern \& Kaplan (1958).

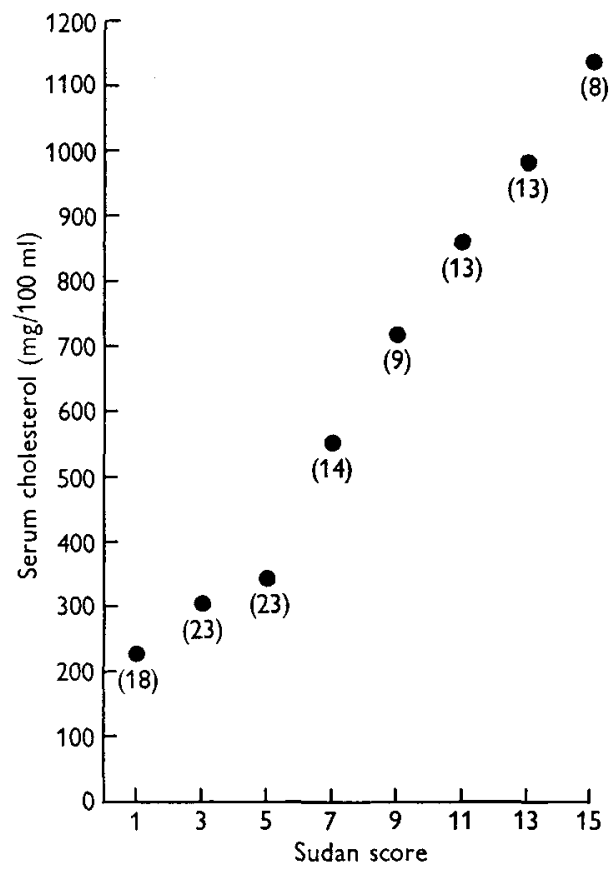

Fig. 5. Relation between sudan score (see p. 228) and serum cholesterol in $12 \mathrm{I}$ female weanling rats receiving modifications of diet $B$ for 4 weeks. The concentrations of serum cholesterol were measured on tail blood at 14 days and on heart blood at 4 weeks. Mean values of these two measurements are plotted. The sudan scores were divided into groups of two units and the middle value of each group was plotted against the mean concentration of serum cholesterol for all animals falling in that group. The number of animals in each group is shown in parentheses.

The combined results from seven experiments, in which type B diets were given to female rats for 4 weeks from weaning, are shown in Fig. 5. To obtain a wide range of serum-cholesterol concentrations, in some of the diets the choline-chloride content was varied between $\circ$ and $\mathrm{I} \cdot 0 \%(\mathrm{w} / \mathrm{w})$, and arachis oil or maize oil was substituted for hydrogenated arachis oil. The concentration of cholesterol in the serum of each animal was measured at 14 days (tail blood) and at 4 weeks (heart blood), the two figures being averaged. The sudan score was evaluated on heart-aorta preparations made at 4 weeks. Results were divided into groups according to sudan score and plotted against the mean serum-cholesterol concentration for each group. The resulting graph shows a high degree of linear correlation between the sudan score and the cholesterol concentration. 


\section{Effect of 3,5,3'-tri-iodo-L-thyronine}

When diet $B$ (arachis oil) containing $T_{3}$ was given to female rats for ${ }^{4} 4$ days from weaning, the concentrations of cholesterol in the serum did not rise to the values obtained on diet B alone (Fig. 6). The concentration of cholesterol in the serum of rats given $0.2 \mathrm{mg} \mathrm{T}_{3} / \mathrm{kg}$ diet was about one-half that of the rats not receiving it. Increasing the dose level had no further effect on cholesterol concentration.

When diet $\mathrm{B}$ containing $0.25 \mathrm{mg} \mathrm{T} / \mathrm{kg}$ was given to female rats for 8 weeks from

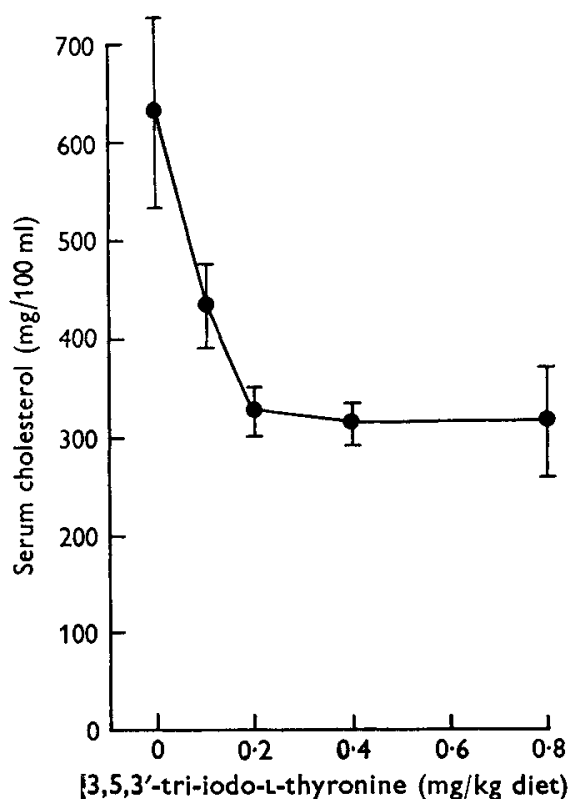

Fig. 6. Effect of 3,5,3'-tri-iodo-L-thyronine on the concentration of cholesterol in the serum of female rats receiving diet $\mathrm{B}$ (arachis oil) for $\mathrm{I} 4$ days from weaning. Each point represents the mean value for ten rats. The vertical lines through the points represent twice the standard errors of the means.

\section{Table 6. Effect of dietary 3,5,3'-tri-iodo-L-thyronine on serum cholesterol and sudan score (see p. 228)}

(Mean values with their standard errors for five female rats receiving the diets from weaning. Cholesterol determinations were made on tail blood at 14 and 42 days, and on heart blood at 28 and 56 days)

Diet $\mathrm{B}+0.25 \mathrm{mg}$ 3,5,3'-tri-iodo-L-thyronine/kg $3,5,3^{\prime}$-tri-iodo-L-thyronine $/ \mathrm{kg}$

$\begin{array}{ccc}\begin{array}{c}\text { Time on } \\ \text { diet } \\ \text { (days) }\end{array} & \begin{array}{c}\text { Serum } \\ \text { cholesterol } \\ (\mathrm{mg} / \mathrm{ro0} \mathrm{ml}) \\ 1062 \\ 14\end{array} & \begin{array}{c}\text { Sudan } \\ \text { score } \\ \pm 116 \cdot 7\end{array} \\ 28 & - \\ 507 & 8.8 \\ & \pm 50.5 & \pm 0.80 \\ 42 & \begin{array}{c}1150 \\ \pm 140.3\end{array} \\ 56 & \begin{array}{c}1094 \\ \pm 157.8\end{array} & \begin{array}{c}14.8 \\ 51.02\end{array}\end{array}$
diet

$\begin{array}{cc}\begin{array}{c}\text { Serum } \\ \text { cholesterol } \\ (\mathrm{mg} / \text { I00 ml })\end{array} & \begin{array}{c}\text { Sudan } \\ \text { score }\end{array} \\ 372 & - \\ \pm 80.6 & \\ 447 & 4.5 \\ \pm 8 \mathrm{r} \cdot 2 & \pm 0.92 \\ 538 & - \\ \pm 40 \cdot 3 & \\ 48 \mathrm{I} & 7.4 \\ \pm 39 \cdot 2 & \pm 0.84\end{array}$
diet

\begin{tabular}{|c|c|}
\hline $\begin{array}{l}\text { Serum } \\
\text { cholesterol } \\
(\mathrm{mg} / 100 \mathrm{ml})\end{array}$ & $\begin{array}{l}\text { Sudan } \\
\text { score }\end{array}$ \\
\hline $\begin{array}{c}455 \\
\pm 59.8\end{array}$ & - \\
\hline 509 & 4.0 \\
\hline $\pm 33 \cdot 1$ & \pm 0.55 \\
\hline $\begin{array}{r}33^{\circ} \\
+21.4\end{array}$ & - \\
\hline $\begin{array}{r}407 \\
\pm 27.8\end{array}$ & $\begin{array}{r}6 \cdot 8 \\
+\mathrm{r} \cdot 34\end{array}$ \\
\hline
\end{tabular}


weaning, neither the concentration of cholesterol in the serum, nor the sudan score, rose to the values obtained when diet $B$ alone was given (Table 6). Increasing the dose to $0.5 \mathrm{mg} \mathrm{T} / 3 / \mathrm{kg}$ diet did not increase the effects. $\mathrm{T}_{3}$ also partly prevented the formation of lesions in the heart muscle.

\section{Regression of lesions}

An experiment (Fig. 7) was carried out to determine whether the sudanophilic lesions could be made to regress by dietary modifications that would decrease the concentration of serum cholesterol. A group of thirty female WAG weanling rats

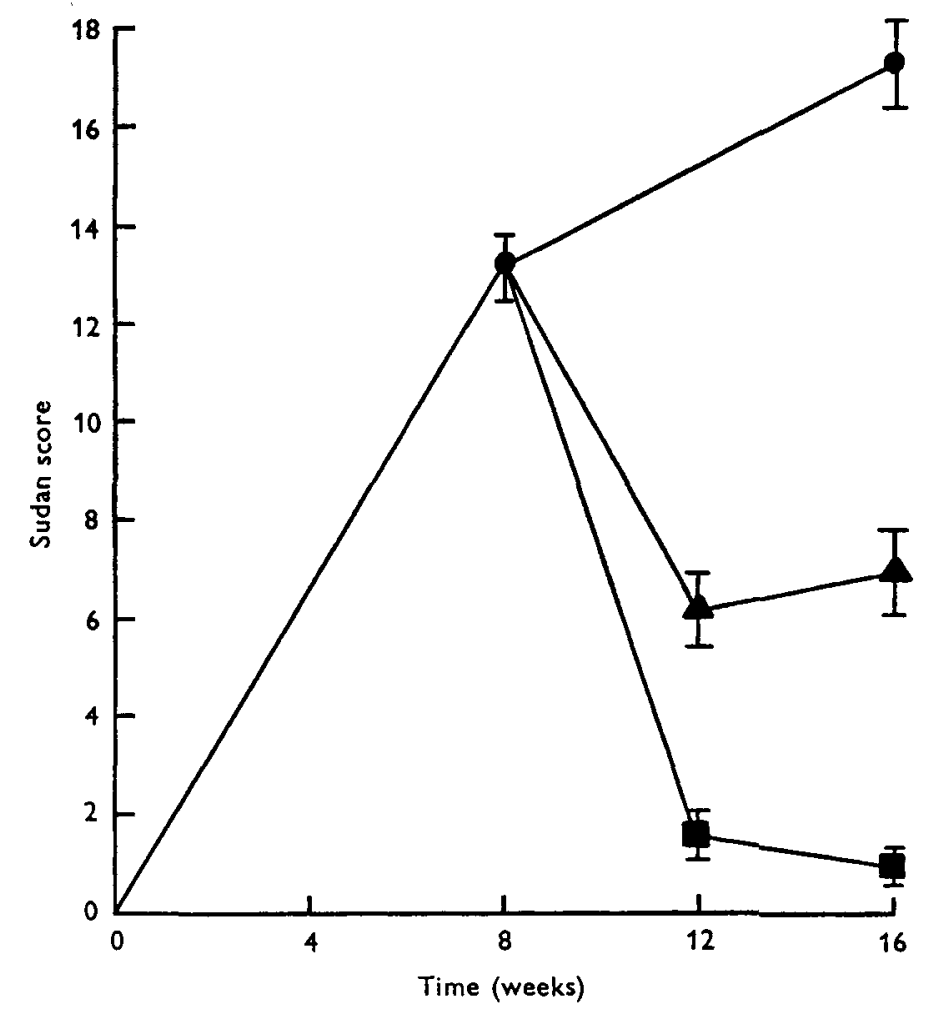

Fig. 7. Regression of sudan score (see p. 228). Thirty female rats received diet $B$ for 8 weeks from weaning, then five rats were killed. Diet $B, \bullet$, was given for a further 8 weeks to five of the rats,

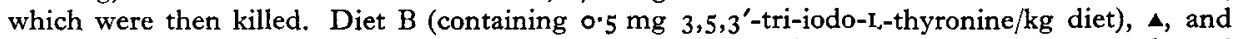
$\operatorname{diet} A, \square$, were each given to ten of the remaining rats of which five were killed after 4 weeks and the others after 8 weeks on the new treatment. Each point represents the mean value for five rats. The vertical lines through the points represent twice the standard errors of the means.

was given diet $B$ for 8 weeks; five animals were then killed to determine the concentration of serum cholesterol and the sudan score, which were found to be $632 \pm 54 \mathrm{mg} /$ $100 \mathrm{ml}$ and $13.2 \pm 0.7$, respectively. Five of the surviving animals were maintained on diet $\mathrm{B}$ for a further 8 weeks, ten were transferred to diet $\mathrm{A}$ and the remaining ten were kept on diet $B$ in which $0.5 \mathrm{mg} \mathrm{T}_{3} / \mathrm{kg}$ had been incorporated. Five of the animals in each of the last two groups were killed after 4 weeks and five after 8 weeks on the new diets. Continued administration of diet $\mathrm{B}$ led to no further change in the con- 
centration of serum cholesterol $(610 \pm 15 \mathrm{mg} / \mathrm{I} 00 \mathrm{ml})$ but the sudan score increased to I7.4 \pm 0.9 . Transfer to diet A led to a decrease, after 4 weeks, in the serum-cholesterol concentrations and the sudan scores to $63 \pm \mathrm{r} \cdot 5 \mathrm{mg} / \mathrm{ro0} \mathrm{ml}$ and $\mathrm{r} \cdot 6 \pm 0.5$, respectively. There was little further change after 8 weeks, when values of $77 \pm 4.5 \mathrm{mg} / 100 \mathrm{ml}$ and $\mathrm{I} \cdot 0 \pm 0.2$ were obtained. A decrease in the concentration of the serum cholesterol and regression of the sudanophilic lesions were also obtained in the animals given $T_{3}$. In these rats the concentration of serum cholesterol and the sudan score decreased to $326 \pm 28 \mathrm{mg} / \mathrm{roo} \mathrm{ml}$ and $6 \cdot 2 \pm 0 \cdot 8$, respectively, after 4 weeks, and were $35^{2} \pm 23 \mathrm{mg} /$ I00 $\mathrm{ml}$ and $7 \cdot 0 \pm 0 \cdot 9$, respectively, after 8 weeks.

\section{DISCUSSION}

\section{Effects of diet on the concentration of cholesterol in the serum and the liver}

Dietary cholic acid caused an increase in serum cholesterol (Table 2), as has previously been observed by Swell et al. (1953) and Hegsted et al. (1957). However, in the tests on our older rats (Fig. 4) the serum-cholesterol levels rose more rapidly than in those of Swell et al., a difference that may have been due to the low fat content of their diets. In our tests on young rats maximum serum- and liver-cholesterol values were obtained with $0.5 \%(\mathrm{w} / \mathrm{w})$ cholic acid in the diet, whereas Hegsted et al. (1957), using adult rats of a different strain, found the response to $135 \%(\mathrm{w} / \mathrm{w})$ cholic acid to be much greater than to $0.45 \%(\mathrm{w} / \mathrm{w})$ in a variety of diets.

The effect of dietary additions of choline (Table 3) was broadly similar to that noted by other workers (Moyer et al. 1956; Weiss et al. 1952), in that this compound can increase the concentration of serum cholesterol. Under our conditions serumcholesterol levels in young male and female rats were raised by the incorporation of $0.25 \%(\mathrm{w} / \mathrm{w})$ choline chloride in the diet. Sometimes, but not invariably, a greater increase followed the addition of $\mathrm{I} \%(\mathrm{w} / \mathrm{w})$ choline chloride. Liver-cholesterol levels were higher in young female than in young male rats at all levels of choline intake.

Dietary cholesterol increased the serum- and the liver-cholesterol levels of young rats (Table 4), the effects being more pronounced on diets containing added cholic acid and fat, as has been shown by other workers, e.g. Hegsted et al. (1957). Both the liver- and the serum-cholesterol levels were higher in rats on a diet containing cholic acid, choline chloride and $22 \%$ fat, but no cholesterol, than on diet A or diet A containing I \% cholesterol. These observed values could not have been due to interference by cholic acid with the determination of cholesterol, because this substance only interferes at high concentrations. It may be concluded that the high values for serum and liver cholesterol of rats given diets of type B are not wholly determined by modifications in the absorption of dietary cholesterol, although this may be the most important factor.

Replacement of dietary hydrogenated arachis oil by arachis oil, or of arachis oil by maize oil, led to a fall in the serum-cholesterol concentrations (Fig. 2), as would have been expected from the work of Hegsted et al. (1957), who demonstrated the effect of various oils on the serum-cholesterol levels of adult male rats.

The response in serum-cholesterol values of the young rats to changes in the dietary fat, as shown in Fig. 2, was similar to that observed in human patients given different 
fats (Bronte-Stewart, Antonis, Eales \& Brock, 1956; Ahrens, Hirsch, Insull, Tsaltas, Blomstrand \& Peterson, I957).

The effect of 3,5,3'-tri-iodo-L-thyronine on serum cholesterol in the rat resembles that on serum cholesterol in man (Oliver \& Boyd, 1956) and that of L-thyroxine on serum cholesterol in the rat (Vitale et al. 1957; Hellerstein et al. 1957).

\section{Effect of sex and age on serum-cholesterol levels}

Serum-cholesterol values reported by other workers who used adult animals on stock rations (McGuire, 1956; Bargeton, Krumm-Heller \& Tricaud, I954; Fillios, Kaplan, Martin \& Stare, 1958) were similar to those found in our rats after a few weeks on diet A (Fig. I), although the fat content of our diet A is greater than that of their diets. The fall in serum cholesterol during the ist week on diet A may have been due to the effects of weaning. The further drop in the serum cholesterol of the males after 3-4 weeks on the diet was similar to that on diet B (Fig. 3) and was possibly consequent on sexual development.

When weanling rats were given diets of type $B$, their serum-cholesterol levels increased rapidly to peak values at about I4 days (Fig. 3). At this age significant differences in the serum-cholesterol values of the sexes sometimes occurred (Tables 2 and 3 ), but were unusual. The serum cholesterol of adults given the same diet increased more slowly (and to lower values) than those of the young rats, and the serumcholesterol values of the sexes were significantly different (Fig. 4). These findings agree with those of Fillios \& Andrus (1957) and of Fillios (1957). After about 3-4 weeks on diet B the serum cholesterol of male rats fell (Fig. 3), and at this age (6-8 weeks) hypertrophy of the testes occurred. It has been observed that on diet B (arachis oil) the serum cholesterol was lower in those animals with the larger testes (Cuthbertson et al. 1958). After puberty the serum cholesterol of male rats given diet B approached values similar to those of the adult males on the same diet (Fig. 4). In young female rats on $\operatorname{diet} \mathrm{B}$ a decrease in serum-cholesterol level was usually observed at about the same time as the depression of serum cholesterol in males, but did not persist (Fig. 4). Sex hormones may cause the difference between the serum-cholesterol levels of adult male and adult female rats given diets producing hypercholesterolaemia, but some other factor regulating the serum cholesterol would seem necessary to explain the different rates of increase in serum cholesterol when young rats and adult rats of either sex are first maintained on diet B.

\section{Relation between sudan score and serum cholesterol}

The relationship between sudan score and serum-cholesterol concentration can be established graphically (Fig. 5). Statistical analysis shows that the changes in sudan score can be completely explained by the changes in cholesterol level, there being no need to postulate any independent effect of diet on the former. Conventional methods of covariance analysis should not be applied to this problem, none of the variables being independent of diet. The canonical analysis of Bartlett (1947) was found applicable to the problem. 


\section{Regression of sudanophilic lesions}

Table 6 shows that dietary administration of $T_{3}$ prevents the serum cholesterol from increasing to levels obtained without it and that it also decreases the rate of development of sudanophilic lesions.

The results summarized in Fig. 7 show that the lesions developed by animals fed on diet $\mathbf{B}$ regress when the serum cholesterol is lowered and that the extent of regression depends on the degree of depression in serum-cholesterol concentrations, whether by changing the diet or by addition of $T_{3}$ to diet $B$.

Pitt-Rivers \& Trotter (1957) and Bainborough \& McMillan (I952), using 3,5,3'tri-iodo-thyroacetic acid and L-thyroxine, respectively, were unable to demonstrate any effect of these agents on established atherosclerotic lesions developed in rabbits fed on diets containing cholesterol. They transferred rabbits with established lesions on to diets without added cholesterol, with and without the drug. In the rabbit, as in the rat, transfer to a diet low in cholesterol leads to a rapid fall of serum cholesterol to normal values, i.e. values of $500-1000 \mathrm{mg} / \mathrm{100} \mathrm{ml}$ are decreased to $50-100 \mathrm{mg} /$ $100 \mathrm{ml}$. Administration of thyroactive compounds to the rabbit on a stock diet may cause some further decrease in serum cholesterol, small compared with that brought about by removal of cholesterol from the diet. Bainborough \& McMillan (1952) in fact did not observe any change in the serum-cholesterol levels of their rabbits on stock diet given $1 \cdot 5 \mathrm{mg}$ L-thyroxine/week. Hence, under the conditions used by Bainborough \& McMillan (I952) or by Pitt-Rivers \& Trotter (1957), thyroactive compounds would not be expected to increase the rate of regression of the lesions if regression is controlled by the serum-cholesterol level in the rabbit, as it is in the rat (Fig. 7). On the other hand, if the thyroactive compounds acted directly on the lesions, then significant effects would have been expected in their experiments, whereas in our tests the effects of 3,5,3'-tri-iodo-L-thyronine might have been expected to have been greater than those noted on transfer to $\operatorname{diet} \mathrm{A}$, but they were not. Consideration of our own and previous work thus seems to indicate that thyroactive compounds do not act directly on the lesions but indirectly through an effect on serum-cholesterol level. This view is supported by the observations of Boyd \& Oliver (I958) who, in tests on the rabbit, showed that administration of $3,5,3^{\prime}$-tri-iodo-thyroacetic acid to rabbits maintained on a diet containing cholesterol led to regression of atherosclerotic lesions, much as was observed in our tests on the rat.

\section{SUMMARY}

I. Weanling rats were given various modifications of a stock diet (A) and a semisynthetic ration (B) for 14 days: the concentrations of total cholesterol in the serum and the liver were determined.

2. Addition of cholesterol to $\operatorname{diet} A$ increased the concentration of cholesterol in the serum by about one-third and in the liver by about two to five times.

3. Serum-cholesterol and liver-cholesterol concentrations were, respectively, about two to three and six to eight times those observed on diet A when a type B diet containing arachis oil but no cholesterol was given. When cholesterol was added to this 
type $B$ diet further increases were noticed in the serum and liver cholesterol levels, of about two and a half and three times, respectively.

4. Cholic acid and choline chloride were both necessary in type B diets to produce maximum concentrations of cholesterol in the serum and the liver.

5. Hydrogenated arachis oil in diet B was more effective than arachis oil in producing hypercholesterolaemia, and arachis oil was more effective than maize oil.

6. Adult female rats on diets $\mathbf{A}$ or $\mathbf{B}$ developed greater concentrations of serum cholesterol than adult male rats, but the concentrations of serum cholesterol in young male and young female rats given the diets for 14 days from weaning were as a rule not significantly different.

7. Weanling rats given diet B developed greater concentrations of serum cholesterol than adult rats on the same diet. The serum-cholesterol concentration of the male rats decreased after puberty, but that of the female rats did not.

8. Sudanophilic lesions developed in the hearts and aortas of female rats given diet $B$ for 12 weeks from weaning.

9. A correlation was apparent between the concentrations of the serum cholesterol and the amounts of sudanophilic material present in the hearts and aortas of rats given various type $\mathrm{B}$ diets for 4 weeks from weaning.

10. 3,5,3'-tri-iodo-L-thyronine in the diet partly prevented the increase in concentration of serum cholesterol and partly prevented the development of sudanophilic lesions in rats given diet $\mathrm{B}$ for 8 weeks from weaning.

I I. Sudanophilic lesions established in rats on diet B partly regressed when they were transferred to diet A or to diet B supplemented with 3,5,3'-tri-iodo-L-thyronine.

We would like to express our thanks to Mr J. P. R. Tootil and Mr B. Basil for advice and assistance with the statistical evaluation of the results obtained in the course of the work reported above.

\section{REFERENCES}

Ahrens, E. H., Hirsch, J. Jr., Insull, W. Jr., Tsaltas, T. T., Blomstrand, R. \& Peterson, M. L. (I957). Lancet, 272, 943 .

Bainborough, D. M. \& McMillan, G. C. (1952). Arch. Path. 54, 204.

Bargeton, D., Krumm-Heller, C. \& Tricaud, M. E. (1954). C.R. Soc. Biol., Paris, 148, 63.

Bartlett, M. S. (1947). F. R. statist. Soc. 9, Suppl. p. 176.

Boyd, G. S. \& Oliver, M. F. (1958). Proc. Conference on Hormones and Atherosclerosis, Brighton, Utah.

Bronte-Stewart, B., Antonis, A., Eales, L. \& Brock, J. F. (1956). Lancet, 270, 52 I.

Cuthbertson, W. F. J., Elcoate, P. V., Ireland, D. M., Mills, D. C. B. \& Shearley, P. (1958). Biochem. F. $68,{ }_{5} P$.

Deming, Q. B., Mosbach, E. H., Bevans, M., Daly, M. M., Abell, L. L., Martin, E., Brun, L. M., Halpern, E. \& Kaplan, R. (1958). F. exp. Med. ro7, 58 I.

Fillios, L. C. (1957). Endocrinology, 60, 22.

Fillios, L. C. \& Andrus, S. B. (1957). Int. Congr. Nutr. Iv, Paris, p. 97.

Fillios, L. C., Andrus, S. B., Mann, G. V. \& Stare, F. J. (1956). F. exp. Med. 104, 539.

Fillios, L. C., Kaplan, R., Martin, R. S., \& Stare, F. J. (1958). Amer. F. Physiol. r93, 47.

Hartroft, W. S., Ridout, J. H., Sellers, E. A. \& Best, C. H. (1952). Proc. Soc. exp. Biol., N. Y., 81, 384.

Hegsted, D. M., Andrus, S. B., Gotsis, A. \& Portman, O. W. (1957). F. Nutr. 63, 273.

Hellerstein, E. E., Vitale, J. J., White, P. L., Hegsted, D. M., Zamcheck, N. \& Nakamura, M. ( 957 ). $\mathcal{F}$. exp. Med. ז06, 767 .

Hubbell, R. B., Mendel, L. B. \& Wakeman, A. J. (1937). F. Nutr. 14, 273.

McGuire, W. B. (1956). Some Aspects of Cholesterol Metabolism in the Rodent. Ph.D. Thesis, University of Edinburgh. 
Moyer, A. W., Kritchevsky, D., Logan, J. B. \& Cox, H. R. (1956). Proc. Soc. exp. Biol., N. Y., 92, 736. Oliver, M. F. \& Boyd, G. S. (1956). Lancet, 27I, I 273.

Pitt-Rivers, R. \& Trotter, W. R. (1957). Brit. F. exp. Path. 38, 97.

Portman, O. W., Mann, G. V. \& Wysocki, A. P. (1955). Arch. Biochem. Biophys. 59, 224.

Swell, L., Flick, D. F., Field, H. Jr. \& Treadwell, C. R. (1953). Proc. Soc. exp. Biol., N.Y., 84, 428.

Vitale, J. J., White, P. L., Nakamura, M., Hegsted, D. M., Zamcheck, N. \& Hellerstein, E. E. (1957). F. $\exp$. Med. 106, 757.

Weiss, S. B., Marx, L. \& Marx, W. (1952). Endocrinology, 50, 192.

Zlatkis, A., Zak, B. \& Boyle, A. J. (1953). F. Lab. clin. Med. 4I, 486. 